Special Issue 特集論文

Invited Peer-Reviewed Article 招待査読論文

\title{
Place Branding in the Age of the New Normal:
}

Short-Term and Long-Term Perspectives of Regional Revitalization

\section{コロナ禍での地域ブランディング}

\section{一 地方活性化策の点と線 —}

\author{
Tetsu Kobayashi ${ }^{* 1}$ \\ 大阪市立大学経営学研究科 \\ 小林哲
}

${ }^{* 1}$ Graduate School of Business, Osaka City University, Japan, kobayashi@bus.osaka-cu.ac.jp

\begin{abstract}
Currently, rural areas have structural problems. Place branding, which leverages the nonresident population, is attracting attention as a solution to these problems. However, the COVID-19 pandemic has prevented this policy from being implemented. In this paper, we consider place branding in the coronavirus crisis from the following three perspectives. (1) Strategies for acquiring a nonresident population during the coronavirus crisis. (2) Development of an alternative market to replace the nonresident population. (3) Possibility of place branding other than through acquisition of a nonresident population. Place branding in the coronavirus crisis requires consideration from a long-term perspective of solving structural problems and a short-term perspective of responding to the particular situation of the coronavirus crisis.
\end{abstract}

Keyword : Place branding, Place marketing, Regional management model, Electronic commerce, Micro-tourism, Ethical consumption

要約 : 地方は, 長期に渡り構造的問題を抱えており, それを解決する方法として注目されているのが, 交流人口を糧とする地域 ブランディング手法に基づく地域経済の活性化である。しかし, 現在, 新型コロナウイルス感染症の蔓延により, その政策が実 行できずにいる。そこで, 本稿では, コ口ナ禍での地域ブランディング政策を, (1)交流人口を維持するための政策, (2)交流人口 に代わる市場の開拓，(3)交流人口以外を糧とする地域ブランディング政策の可能性の 3 つの視点から考察する。なお, コ口ナ禍 での政策には, 構造的問題の解決という長期的視点（線）と，コ口ナ禍という特殊状況への対応という短期的視点（点）の両方 が必要となる。本稿では, この両方の視点を踏まえて, コロナ禍での地域ブランディングの在り方を明らかにする。

キーワード : 地域マーケティング, 地域経営モデル, eコマース, マイクロツーリズム, 応援消費

Information : Received 3 March 2021; Accepted 23 March 2021

\section{I. はじめに}

2020 年 1 月 6 日, 中国武漢で原因不明の肺炎が確認 されたとき, 新型コロナウイルス感染症（以下, COVID-19）は，まだ名も無く，遠く離れた場所での出来 事だった。しかし，全国の小中学校が臨時休校し，東京 オリンピック・パラリンピックの 1 年延長が発表される と, 誰もが身近な問題として考えるようになる。そして,
4 月 7 日に都市部を中心に 7 都道府県で緊急事態宣言が 発令され，4月 16 日にそれが全国に拡大されたことで, 強制的に生活様式の変更を迫られるようになる。

COVID-19 は, 発生当初から 1918 年に大流行したスぺ イン風邪（H1N1 覀型インフルエンザ）との類似性が指 摘され，100 年に 1 度の大規模なパンデミックになると 考えられていた1)。また，スペイン風邪が収束するのに 3 年程度かかったことから, 今回も長期化することが予 想されている。もちろん, 医療技術の進歩は凄まじく, 
短期間でワクチンが開発され，それよりも短期間で収束 するという見方もある（BBC NEWS, 2020）。しかし， ジョンズ・ホプキンス大学の集計によると, 2021 年 1 月 27 日に全世界の感染者が 1 億人を超え, 発生から 1 年近 く経っても新規感染者数は減らず，未だ収束の目途は 立っていない。

そして, COVID-19 は, 都市部のみならず，地方の経 済にも大きな影響を与える。と言うのも，地方は，近年， その地を訪れる交流人口を経済活性化の糧としており, COVID-19により，人々の地域間移動が大きく制限され たことで，この経済活性化策が機能しなくなったからで ある。そこで，本稿では，COVID-19 が地方の経済活性 化に及ぼす影響を，地域ブランディングの観点から考察 する。

ところで，この種の大きな災害が経済に及ぼす影響を 考察するのは難しい。たとえば，阪神淡路大震災で被災 した兵庫県は，単に震烸前の状況に戻すのではなく，新 たな視点から都市を再生する「創造的復興」が必要だと 認識していた（Hamaguchi, 2013）。これは，当時，円高 による地場産業の競争力低下などの構造的問題を抱えて おり，震災前の状況に戻すだけでは，それが解決できな いからである。

同様のことが, COVID-19にも当てはまる。地方は, 現在，大きな構造的問題に直面している。したがって， COVID-19への対応を考える際, 現状維持という “点” の視点と, 構造的問題の解決という “線” の視点の両方 が必要となる。そこで, 次章では, 地方が抱える構造的 問題を, 地域経営モデルの変遷から考察してみよう。

\section{II. 地域経営モデルの転換}

\section{1. 地域経営の基本モデル一自給自足型モデル—}

従来，地方自治体は，当該地域の住民や企業が納める 税収を財源とし，彼らが必要となる行政サービスを提供 するという地域経営モデルを想定していた。これは，地 域で必要な財源を当該地域から確保するという意味で, 地域内の自給自足型モデルだと言える。

しかし，このモデルが成立するのは，住民や企業が増
え，地域内の経済活動が活発に行われている場合である。 なぜなら,このような状況下では, 税収が増加し行政サー ビスが充実することで，新たな住民や企業を呼び込むと いう好循環が生まれるからである。一方，住民や企業が 減少すると, 税収が減少し行政サービスも低下するため, 住民や企業がさらに減少するという悪循環に陥ることに なる。

2014 年に発足した第二次安倍内閣が, 東京の一極集中 を是正し地方の人口減少に歯止めをかける「地方創生」 を，日本経済の中核戦略に位置づけたのもそのためであ る。その骨子となる「まち・ひと・しごと創生総合戦略」 において，地方の人口減少に歯止めをかけるには，若者 が働くための就労環境と生活環境の整備が不可欠だと主 張する 2)。そして，仕事が人を呼び，人が仕事を呼ぶ好 循環をつくることで, 地方の自立を促し, 持続可能な社 会を形成することが「地方創生」の目的だという。

しかし，これがなかなか難しい。と言うのも，「ひと (定住人口)」「しごと (就労環境)」「まち (生活環境)」 は相互依存関係にあり, どれか改善しようと思っても他 の要因がその足を引っ張るため, 一旦悪循環に陥ると, そこから抜け出すことができないからである。ここに， 地方が抱える構造的問題がある。

\section{2. 地域経営モデルの転換一外部資源補充型モデルへの シフトー}

ここで重要となるのが, 外部資源の活用である。地域 経営が上述したような悪循環から抜け出せないのは, 地 域の内部資源に依存しているからであり, 外部から新た な資源を獲得することができれば，この悪循環を断ち切 ることができる。

ところで，地方への外部資源の投入が必要だという認 識はかなり前から存在していた。そもそも日本で地方か らの人口流出が急速に進んだのは 1960 年代に入ってか らである。池田内閣の「国民所得倍増計画」のもと, 都 市部の重化学工業の働き手として地方の第一次産業就労 予定者を大量に動員したのが原因である ${ }^{3)} 。$

このような状況で登場したのが，田中角栄の『日本列 島改造論』である。1972 年に首相に就任した田中角栄 は，第二次産業の地理的再配置と全国交通ネットワーク 
の構築により，1960 年代に地方から都市へと流れたヒ ト・モノ・カネを逆流させることで，地方の過疎と都市 の過密を解消する日本列島改造論を提唱する。

この日本列島改造論は, 1970 年代を通して一定の成果 をあげたが, 1985 年のプラザ合意以降, 円高が進んだこ とで状況が大きく変化する。と言うのも，その主要政策 のひとつだった第二次産業の地理的再配置が，円高によ り国内での製造コストが高くなったことで，生産拠点や 部品の調達を海外に求めるようになり機能しなくなった からである。また，もうひとつの主要政策だった交通ネッ トワーク整備等の公共事業による地方への資金還流も, バブル経済の崩壊により緊縮財政に転じたことで大きく 減少する。そして, 構造的問題が解決されないまま地方 と都市部との格差がますます広がることになる。

こうした状況を打破するために，新たに打ち出された のが「地方創生」である。地方創生は, 地方と都市部の 格差をなくすことで日本全体の活性化を眓るという点で, その目的は 1970 年に提唱された日本列島改造論と同じ である。しかし, その方法は, 1970 年代のそれと大きく 異なる。日本列島改造論では，第二次産業を中央集権的 に地方に再配分することで地方の活性化を図ろうとした が，地方創生では，地方が有する潜在資源を活用し，第 一次産業や第三次産業の持続的発展を促すことで, 自ら 外部資源を獲得することを目的としている。ここに，今 日の地域経営モデルの特徵がある。

\section{3. 地域経営手法としての地域ブランディングの有用性}

以上，地方が抱える構造的な問題を解消するため，地 域経営モデルが，地域の潜在資源を活用しながら，自ら の力で外部資源を獲得し持続的発展を目指す外部資源補 充型へ大きくシフトしていることを示した。その方法と して重要な役割を担うのが地域マーケティングである。 地域マーケティングは，地域を製品とみなし，標的とな る地域外の住民や企業のニーズを満たすことで，自らの 目的達成を目指す（Kotler, Haider, \& Rein, 1993）。

そして, 2000 年代に入り, 地域マーケティングの新た な手法として注目されているのが，地域ブランディング である。地域ブランディングは, 1980 年代後半に登場し たブランド・エクイティ概念に基づくマーケティング手
法である。ブランド・エクイテイとは, ブランドの有す る資産価值であり, 資産価值の高いブランドは, それが 付与された製品のマーケティング活動に好ましい影響を もたらす (Keller, 1993)。

地域ブランディングは, この考え方を地域マーケティ ングに適用しようとするものであり，マーケティング手 法を用いて「名称としての地域 (=ブランド)」の魅力を 高め, それを「実態としての地域 (=製品)」に反映させ ることで，実態としての地域やその産出物に対する認識 を変えたり，評価を高めることを目的としている (Kobayashi, 2016)。本来, 地域の名称は, 特定の地理的 空間を識別するための記号に過ぎない。しかし，それを ブランドとみなすとき，地域の名称はそれ以上の価值を 有する。事実,「京都」「軽井沢」「銀座」といった地域名 称は，製品やサービスに対する認識を変え，評価を高め る力を有している。

\section{COVID-19 発生前の地域ブランディング政策}

\section{1. 外部資源としての交流人口}

ここで, COVID-19 が発生する前の地域ブランディン グ政策について述べておこう。前章で示した通り，地域 ブランディング政策では，地域の魅力を高めながら自 らの力で外部資源を獲得することが求められるが, COVID-19 が発生する前, 獲得すべき外部資源として注 目されていたのが交流人口である。交流人口とは，通勤・ 通学，ビジネスや観光といった目的を問わず当該地域を 訪れる人を指すが, 定住人口が高齢化し減少する中, 交 流人口により地域内需要を増やすことで経済活性化を図 ることができる。

図 1 は, 鉄道を利用した移動状況の推移を示したもの であるが，定期券を利用した通勤・通学の移動はほとん ど増えていないが, 定期券以外での移動は, 2008 年に発 生したリーマンショックにより一時的に落ち込んだもの の，それ以降回復し増加しているのがわかる。これは， 通勤・通学以外のビジネスや観光での移動が増えている ことを示すものであり, 地方にとって交流人口を増やす 可能性が高まっていることを示している。 
（100万人キロ）

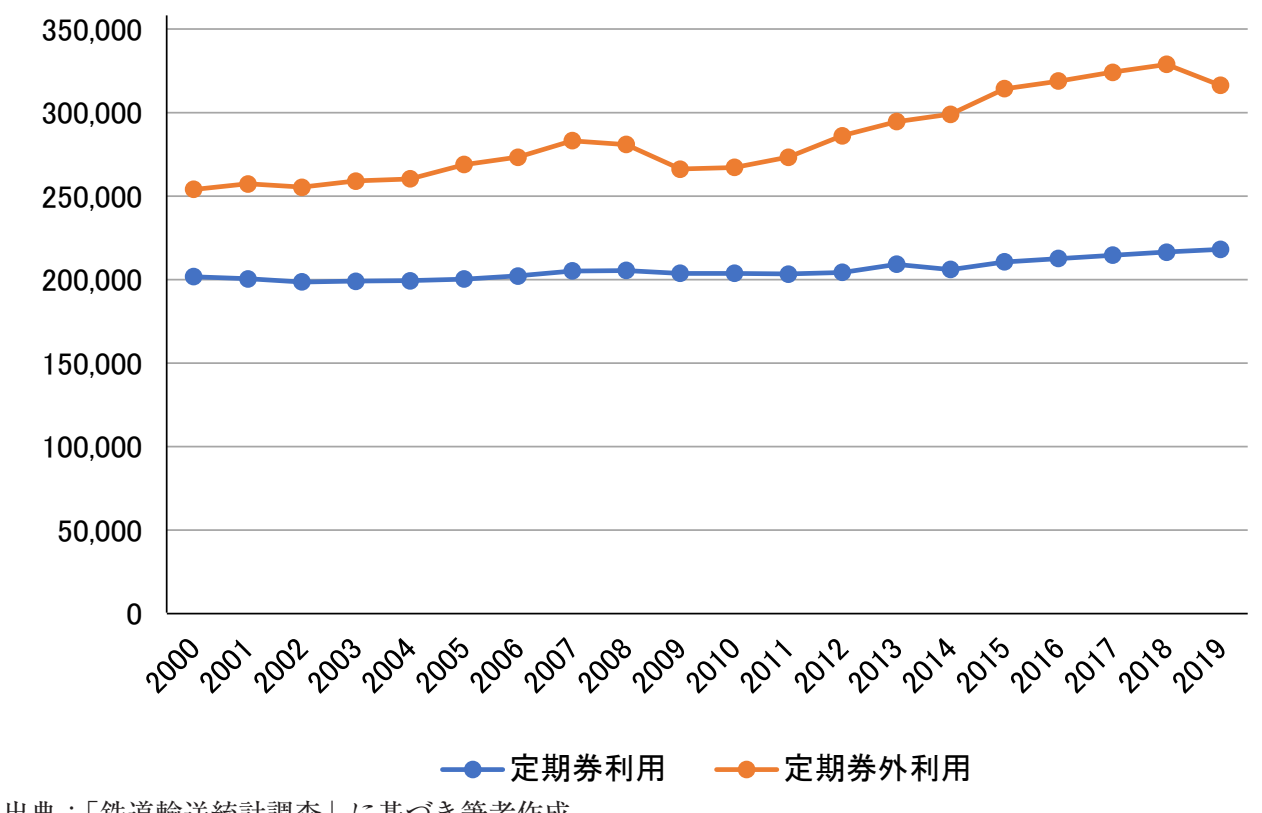

出典：「鉄道輸送統計調査」に基づき筆者作成

また，交流人口拡大策として，国内旅行者とともに注 目されているのが，インバウンドすなわち訪日外国人旅 行者である。図 2 は, 日本人の出国者数と外国人の入国 者数の推移を示したものだが，日本人の出国者数がほぼ 横ばいで推移しているのに対し, 外国人の入国者は, リー マンショックや東日本大震災の影響で一時的に減少する ものの, 2012 年には増加に転じ, 2019 年には 2012 年の 3.4 倍まで増加する。

そして, 訪日外国人旅行客の多くが, 地方も訪問して いる。たとえば, 2014 年の「訪日外国人消費動向調查」 によると，東京と大阪の 2 大都市圈のみ訪問した人は全 体の $44 \%$ で, 2 大都市圈と地方の両方を訪問した人が $28 \%$, 地方のみ訪問した人が $28 \%$ となっており，地方を 訪れる人が過半数を上回っている（The Japan Tourism Agency Strategy Planning Division, 2015)。

\section{2. 交流人口拡大のための地域ブランディング政策}

以上，交流人口のパイ自体が増加していることを示し たが，地方は彼らを呼び込むためにどのような地域ブラ
ンディング政策を行っているのだろうか。

第一は, 既存の観光資源の活用である。地方には, 観 光客を惹きつける山岳や海岸, 温泉などの自然観光資源 や，史跡，庭園などの人文観光資源が多数存在する。ま た, 北海道ニセコのパウダースノーや長野県地獄谷野猿 公苑の温泉に入る野生の猿など, 観光資源としての価值 が訪日外国人によって見直されたものも数多く存在する。

第二は, 新たな観光資源の創出である。たとえば, 現 在アートを利用して地域の再生・創出を図る香川県直島 のアートプロジェクトや, 青森県田舎舘村で 1993 年に 始まり，国内外で注目を集め，全国に広がった「田んぼ アート」などの期間限定イベントも新たな観光資源の創 出による地域ブランディング政策である。

第三は, ニューツーリズムの開発である。ニューツー リズムは, 従来の物見遊山的な観光ではなく, テーマ性 が強く, 体験や地元の人との交流といった要素を取り入 れた新しい形態の旅行であり, 観光地が企画する個人旅 行者を対象とした着地型観光である点が, 従来のマスツー リズムと異なる点である（Oie, 2010; Tomimoto, 2016）4)。 
(人)

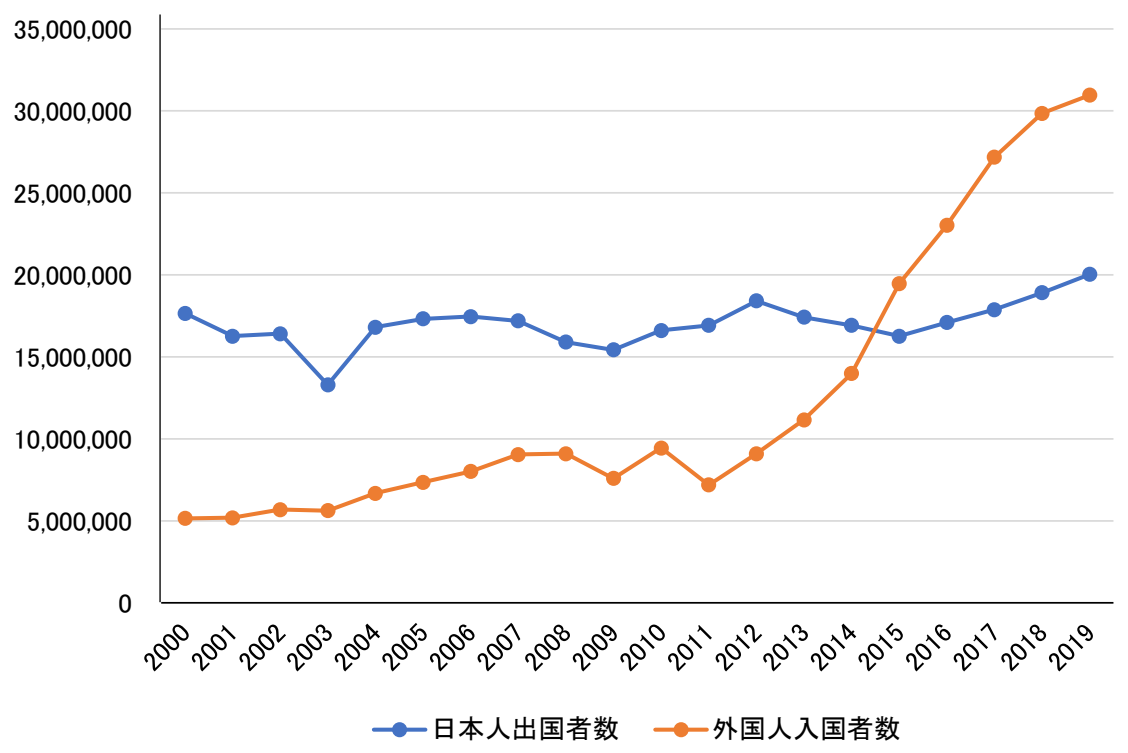

出典 :「出入国管理統計表」に基づき筆者作成

表 1 ニューツーリズムのタイプ

\begin{tabular}{|c|c|c|c|}
\hline & カテゴリ（テーマ） & 観光資源 & 観光アトラクション \\
\hline 1 & $\begin{array}{l}\text { エコ・ツーリズム } \\
\text { (環境教育) }\end{array}$ & $\begin{array}{l}\text { 良好な生態系, 自然景観, 伝統的生活文化, } \\
\text { 住民, 専門家 }\end{array}$ & $\begin{array}{l}\text { 環境教育プログラム, 動植物生態観察, } \\
\text { 伝統文化体験 }\end{array}$ \\
\hline 2 & $\begin{array}{c}\text { グリーン・ツーリズム } \\
\text { (農村漁村滞在) }\end{array}$ & 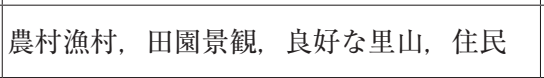 & $\begin{array}{l}\text { 農家滞在, 農村景観, 農 業体験, 伝統的 } \\
\text { 生活体験 }\end{array}$ \\
\hline 3 & $\begin{array}{c}\text { ヘリテージ・ツーリズム } \\
\text { (文化遺産・産業遺産) }\end{array}$ & $\begin{array}{l}\text { 文化財, 歴史的建造物, 街並み景観, 産業 } \\
\end{array}$ & $\begin{array}{l}\text { 文化遺産教育, 街並みのレストラン・喫茶 } \\
\text { 店・カフォみや物屋 }\end{array}$ \\
\hline 4 & $\begin{array}{l}\text { ヘルス・ツーリズム } \\
(\text { 健康・保養・治癒 })\end{array}$ & $\begin{array}{l}\text { 森林, 海洋, 温泉, ヒーリングスポット, } \\
\text { 医療機関 }\end{array}$ & 健康于 \\
\hline 5 & $\begin{array}{l}\text { フード・ツーリズム } \\
\text { (食文化・美味体験) }\end{array}$ & 地方料理, 美食, 特産物, 料理人 & $\begin{array}{l}\text { レストラン, 料亭, ワイナリー, ご当地 } \\
\text { グルメ, 農家レストラン, 農産物販売所 }\end{array}$ \\
\hline
\end{tabular}

出典 : Oie (2010), p. 33, Table 5

なお，ニューツーリズムのタイプとして，「エコ・ツーリ ズム（環境教育）」「グリーン・ツーリズム（農村漁村滞 在)」「ヘリテージ・ツーリズム（文化遺産・産業遺産）」 「ヘルス・ツーリズム（健康・保養・治癒）」「フード・ ツーリズム（食文化・美味体験）」などがあげられる (表1 参照)。

\section{3. 交流人口から関係人口, 定住人口の拡大へ}

そして，地域ブランディングでは，増加した交流人口
を，関係人口や定住人口にいかに移行するかが課題とな る。定住人口は, 文字通り, その地に住んでいる人のこ とを指すが, 関倸人口は, 何らかのかたちでその地域に 関わってくれる人のことである（Odagiri, 2019）。関係人 口という言葉が登場したのは新しく，「東北食べる通信」 編集長の高橋博之氏や，SDGs マガジン「ソトコト」編 集長の指出一正氏が, 2016 年に自身の著書の中で使用し たのが最初と言われている（Iwashiro, 2018）。

関係人口は, 特産品の購入から, 寄付 (ふるさと納税), 


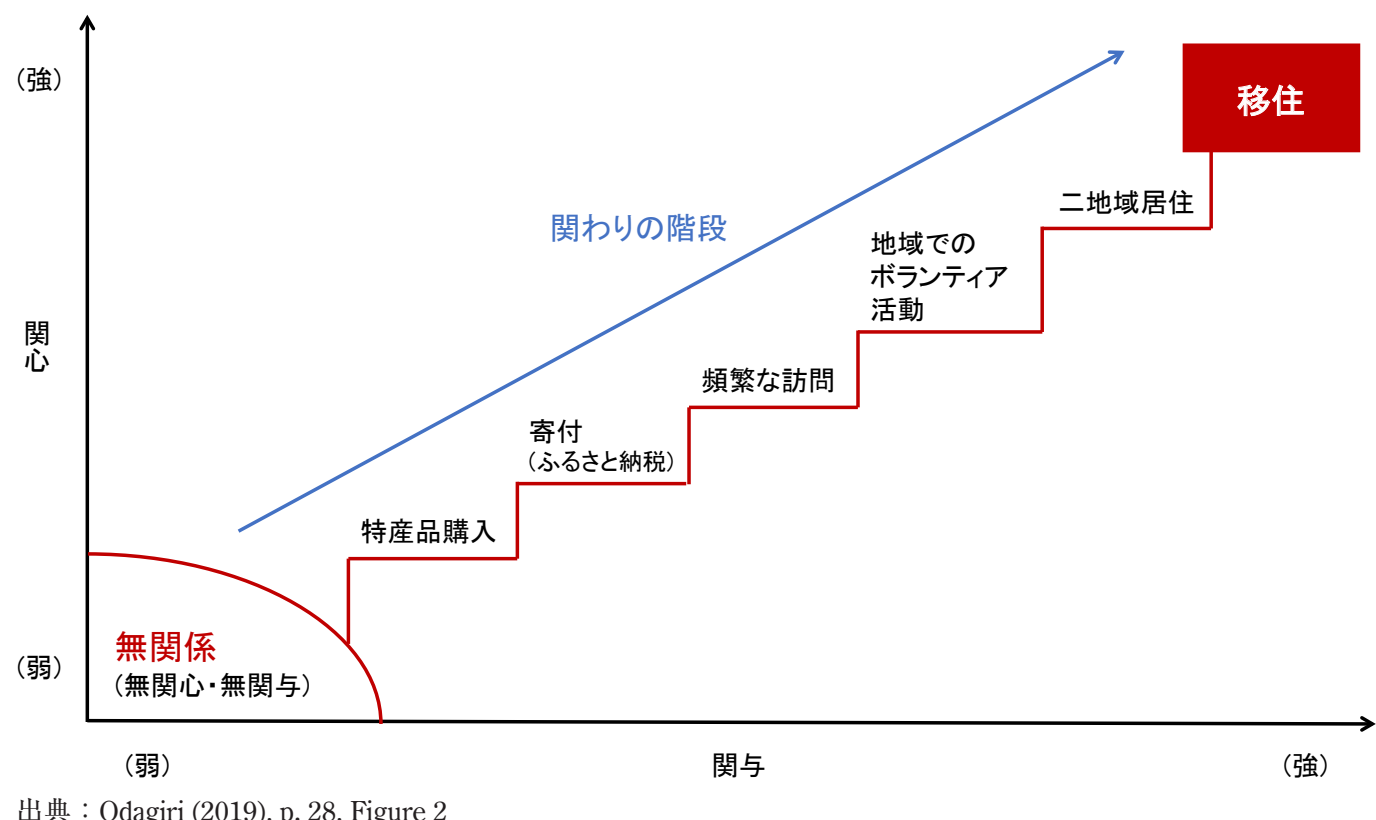

頻繁な訪問, 現地ボランティア活動, 2 地域居住へと地 域との関わりを深め, 最終的に移住へと向かうことから, 交流人口から定住人口への移行プロセスとみなすことが できる(図 3 参照)。

しかし，彼らのすべてが定住人口に移行するわけでは ない。なかには関係人口に留まり続ける人もいる。そし て, 高橋氏や指出氏は, そのような人たちの存在も地方 にとっては重要だと言う。なぜなら, 彼らは, 地域のファ ンとして，地域の特産物を定期的に取り寄せたり，何度 も地域を訪れたり，SNS 等で地域の良さを発信するだけ でなく，住民と一緒に地域の課題に取り組んだり，現地 側のスタッフとして地域のイベント等に積極的に関わっ てくれるからである（Iwashiro, 2018）。

以上, COVID-19 が発生する前の主要な地域ブランディ ング政策について述べてきた。それは，日本人の観光に 対する関心の高まりや，訪日外国人の増加を背景に，地 域に固有な資源を活用して彼らのニーズに応える製品や サービスを開発し，交流人口を増やすことを目的として いる。そして，増加した交流人口を関係人口や定住人口 に移行することで，地域資源のさらなる向上を図るとい うものである。
次章では，上述した地域ブランディング政策が， COVID-19により，どのような影響を受けているのか。 そして, COVID-19 の影響下および収束後の地域ブラン ディング政策がどうあるべきか考えてみようと思う。

\section{CIVID-19 が地域ブランディングに与えた影 響とそれへの対応}

\section{COVID-19 の負の影響}

COVID-19 が地域ブランディング政策に与えた影響の 中で，特に大きいのが交流人口の減少である。

図 4 は, 2019 年 12 月から 2020 年 11 月までの 1 年間 の月別鉄道利用状況を示したものだが，地方の交流人口 に影響を与える定期券以外の鉄道利用を見ると, 緊急事 態宣言が発令される 1 か月前の 3 月から大きく減少し始 め, 4 月は対前年比 $20 \%$ 近くまで落ち込み, その後徐々 に回復したものの，2020 年 11 月時点で対前年比 $60 \%$ 程 度にとどまっている。

一方，COVID-19 発生前に地方の交流人口拡大に大き く寄与した訪日外国人旅行客は，パンデミックが収まら 


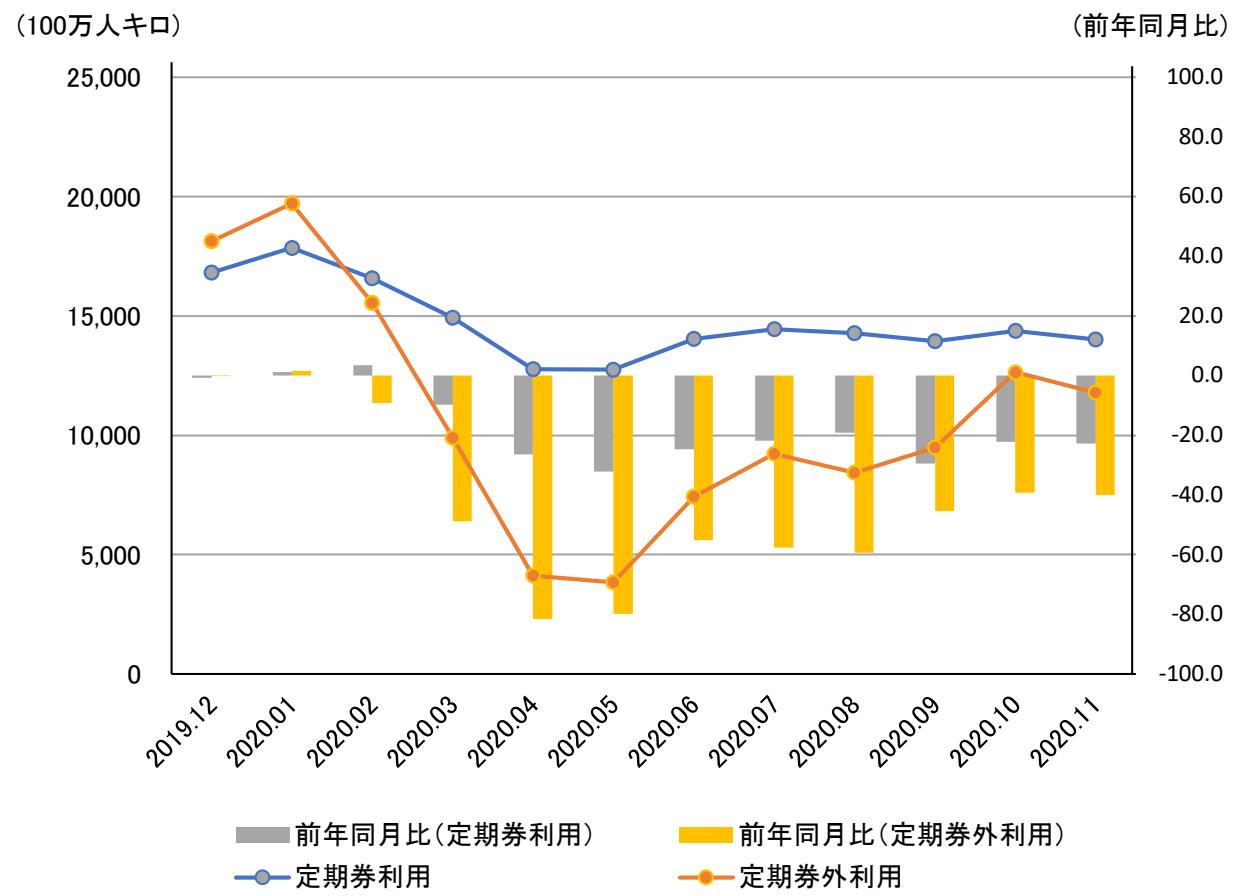

出典：「鉄道輸送統計調査」に基づき筆者作成

ず，壊滅状態にある。図 5 は, 2019 年 12 月から 2020 年 11 月までの月別出入国者数を示したものだが，2月に外 国人入国者数が激減し，4 月から 9 月までの 6 か月間は, 対前年比 $1 \%$ 未満で，11 月になっても対前年比 $2.8 \%$ と ゼロに近い状態が続いている。

\section{COVID-19 の正の影響}

しかし, COVID-19 が地方にもたらした影響は悪いこ とばかりではない。

COVID-19 の対策として，マスクの着用や手洗いが推 奨されているが，それとともに重要なのが 3 密（密閉・ 密集・密接）の回避である。この 3 密が生じやすいのが 都市であり，非常事態宣言が最初に発令され，最後まで 解除されなかったのが都市部だったことも，3 密が発生 しやすい環境と無関係ではない。都市の魅力は, 多くの 人々を吸引する商業施設の集積や大規模なイベントの開 催にあるが，COVID-19 により，人々はその魅力を十分 に享受できずにいる。
こうした状況の中，都市と地方に対する人々の見方も 変わりつつある。内閣府の「第 2 回新型コロナウイルス 感染症の影響下における生活意識・行動の変化に関する 調査」によると, 地方移住に関心がある人は, 2019 年 12 月の調査で, 首都圈 (東京都・神奈川県 - 千葉県・埼 玉県）が $25.1 \%$ ，東京都区部が $28.0 \%$ だったが，2020 年 12 月の調査では，首都圈が $28.0 \%$, 東京都区部が $36.5 \%$ に増加している（Cabinet Office, 2020)。なお, 2020 年 4 月から 10 月にかけて, 東京都区部, 東京都, 首都圈す べてで転出超過となっており, 東京都心部への人口集中 は一服し，地方に人々が流れている（Okada, 2020)。こ れは, 定住人口の増加を目指す地方にとって良い傾向だ といえよう。

\section{COVID-19への対応}

（1）交流人口以外の市場開拓

以上, COVID-19 が地域ブランディングに与えた影響 についてみてきた。その中でも，特に深刻なのが交流人 
(人)

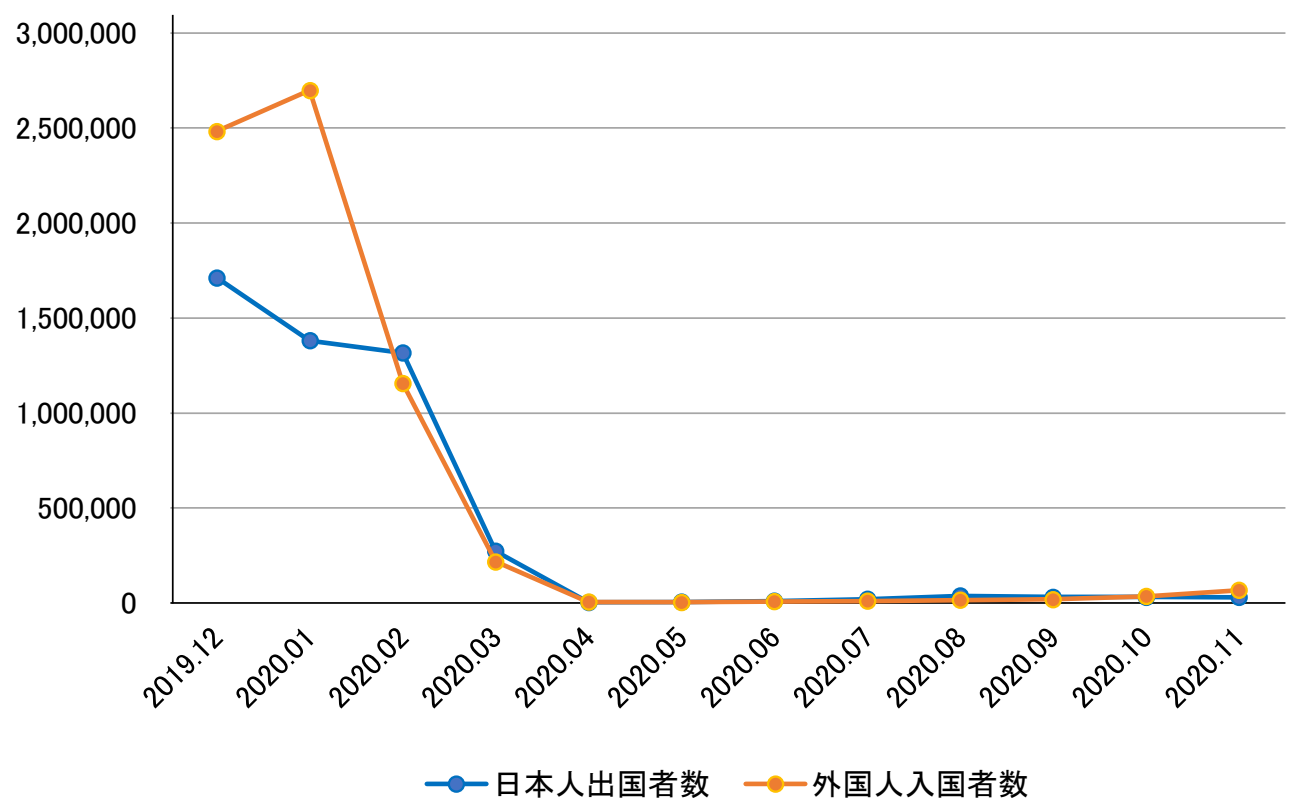

出典 :「出入国管理統計表」に基づき筆者作成

口の減少である。と言うのも, COVID-19 発生前の地域 ブランディング政策が，交流人口の獲得に大きくシフト していたからである。

そこで，交流人口が減少した地方では，それに代わる 新たな市場を模索している。たとえば，沖縄県産の紅芋 を $100 \%$ 使用している（株）御菓子御殿の「紅いもタル 卜」は，観光客の減少により，2020 年 7 月から 10 月の 売上が前年の半分以下に落ち込んだ (The Okinawa Times, 2020）。その際，製品の販売とともに問題になったのが, 原料となる紅芋の在庫である。(株) 御菓子御殿は, 紅い もタルトの販売減により, 例年の 4 倍の 200 トンの在庫 を抱えているという。それでも, 長年取引している生産 農家から紅芋をすべて買い取っているが，新規や定期的 な取引のない農家からの仕入は中止しており，その影響 は地元の農家にも及んでいる。

このような状況において, (株) 御菓子御殿は, 紅芋の 販路拡大のため, さまざまな対策を講じている。第一は, 紅いもタルトの值下げ販売である。これは, 緊急事態宣 言の発令で, 紅いもタルトの販売が対前年比 1 割まで落
ち込んだ 2020 年 4 月にとられた措置で, 通常価格の半 額で販売した。その目的は, 賞味期限のある製品の廃棄 を減らすためだが, 地元住民の購入を促す目的もあった という（The Ryukyu Shimpo, 2020）。第二は, 新たな販 路の開拓である。(株) 御菓子御殿では, 以前から紅いも タルトの通販を行っていたが, COVID-19 による生産量 減少を受け, 県内外の法人・個人を対象に「紅いもペー スト」の販売を開始した（Nikkan Kogyo Shimbun, 2020）。 そして, 第三は, 新たな製品の開発である。(株) 御菓子 御殿は, 2021 年 1 月 22 日の「カレーの日」に合わせ, レトルト食品の「紅いもカレー」を発売した5)。「紅いも カレー」には, 紅芋の他に沖縄県産の紅豚も入っており, カレーを共同開発した（株）食のかけはしカンパニーと ともに, 地元企業とパートナーシップを組むことで地域 活性化につながることが商品化に至った理由だという。

\section{(2) COVID-19 影響下での地域産品販売}

上述した（株）御菓子御殿の例にみられるように, 交 流人口に代わる市場開拓にはさまざまな方法が存在する 
が，その中心となるのは地域外の人々に対する地域産品 の販売であろう。もちろん，地域外一の地域産品の販売 は, COVID-19 発生前から行われており，交流人口に焦 点をあてた地域ブランディング以前の主要政策のひとつ だった。しかし, COVID-19 影響下での地域産品の販売 は，以前のそれと少し様相が異なる。

ひとつは, 間接販売から直接販売へのシフトである。 以前の地域産品の販売は, その波及効果の高さもあって, 都市部の小売店やレストランを利用した間接販売が主 だった。しかし，これらの店舗が営業自肃や営業時間の 短縮で上手く機能しなくなっている。そこで注目される のが，インターネット等を活用した顧客への直接販売で ある。三井住友カード（株）と（株）顧客時間の調查に よると，COVID-19 の影響下で年齢を問わず EC モール や通販の利用が増加しており，地域ブランディングにお いても，いかにインターネット等を利用して顧客に直接 販売するかが大きな課題となっている6)。

もうひとつは，地方やその生産者の応援という製品の 品質や価格以外の動機付けである。もちろん，製品の品 質の高さや価格の安さは，製品の購買を促す上で重要な 要素である。しかし，それだけが，顧客の購買意欲を刺 激するわけではない。たとえば，産直 EC サイトの「食 ベチョク」は，COVID-19 で困っている生産者から相談 を受け，2020 年 3 月から生産者応援プロジェクトを開始 した。支援内容は，「\#コロナで打困りの生産者さん」と いう特設ページを設け，生産者が困っている状況を伝え るとともに，送料（500 円分）を「食べチョク」が負担 するというものである（Funada, 2020）。

なお，この支援プロジェクトは，当初 3 月末までの予 定だったが，生産者支援の重要性を考慮し 2020 年 5 月 末まで延長するとともに，2020 年 5 月末からは，農林水 産省が指定商品の配送料を全額負担する「品目横断的販 売促進緊急対策事業におけるインターネット販売促進事 業」に参加し，生産者への支援を行っている7)。

\section{（3）交流人口維持のための新たなツーリズムの開発}

ところで，交流人口の獲得を目指す地域ブランディン グはどうなっているのだろうか。交流人口の獲得は， COVID-19の影響下でも，地方にとって重要な地域ブラ
ンディング政策であることに変わりはなく, 厳しい状況 ではあるが，何らかの方法で維持することが求められる。

そこで注目されるのが，マイクロッーリズムである。 マイクロッーリズムとは, 自宅から 1〜2 時間程度で行 ける近距離旅行で, COVID-19 の打撃を受けた観光業界 を救う手段のひとつとして, 星野リゾート代表の星野佳 路氏が提唱した概念である（Hoshino, 2020）。マイクロ ッーリズムは, 広域移動による COVID-19 の拡散を防ぐ だけでなく，地元の魅力の再発見や地元の人々との交流 を深めるといった遠距離旅行とは別の魅力を有している。

また，交流人口の維持という点では，オンライン体験 ッアーも注目すべき方法のひとつにあげられる。オンラ イン体験ッアーは，インターネットを利用して，自宅に いながら現地の映像を見たり，現地の人々と交流するこ とで，旅行を疑似体験することをいう。大手旅行会社 HIS のサイトには，167 件の国内オンライン体験ツアー が掲載されており（2021 年 2 月 25 日現在），その内容 は, 景勝地や歴史的建造物などの見学ツアーや，自然観 察やスタディ・ッアーなどの学びをテーマとしたツアー, 鉄道の旅や映画・アニメの口ケ地巡りといった特定のファ ン向けッアーなど多岐にわたる。

その中でも人気なのが, 現地から食材や商品が送られ てきて, 現地の人の話を聞きながら，それを調理し味わっ たり使用するといった，現地との結びつきがより強く感 じられる体験ッアーである。たとえば，富山県が主催し ている「オンラインとやまトラベル」では，ツアー当日 までに，富山湾で捕れたシロエビとそれに合う地酒が届 き，それらを味わいながら，持続可能なシロエビ漁を実 践している漁師と地酒を選んだ杜氏の話を聞くというオ ンライン体験ツアーを実施し好評を得ている ${ }^{8)}$ 。

(4) COVID-19 収束後のツーリズムに対する価值観の変化

以上，地域ブランディング政策において COVID-19 の 影響下で取り組むべき交流人口維持策として，マイクロ ッーリズムとオンライン体験ツアーを取り上げたが, COVID-19 収束後のツーリズムはどうなるのだろうか。

この点に関し, Okamoto（2020）は, 旅行に対するニー ズは変わらないものの, COVID-19 を経験したことで旅 行に求める内容は変化するとし, 以下の 3 点をあげてい 
る。第一は, 旅行の意義に関してある。旅行する際に, 家を離れる必要があるか, その地に行く必要があるかが 問われるようになり，以前にも増して旅行する意義を明 確にする必要があるという。第二は, サステイナブルッー リズムの重視である。旅行が激減したことで, オーバー ツーリズムの弊害が浮き彫りになり，COVID-19 収束後 は, 自然環境や地元住民に配慮した持続可能なツーリズ ムへの関心が高まるという。第三は, ツーリズムにおけ るリアルとバーシャルの融合である。オンライン体験ツ アーを経験したことで, バーチャルなりの良さを認識し, リアルでなければできないことを重視するとともに，才 ンラインでレクチャーを受けた後, リアルな旅行を楽し むなど，リアルとバーチャルを融合したツアーも誕生す ることが予想される。

\section{（5）定住人口拡大の可能性}

最後に, COVID-19 がもたらした地域ブランディング の新たな可能性について述べておこう。前節で説明した 通り，COVID-19 が地方にもたらした影響は悪いことだ けでない。都市が本来の機能を果たせなくなったことで, 地方での生活があらためて注目されている。

従来の地域ブランディングでは，まず交流人口を増や し，彼らとの関係を深めることで定住人口に導くという のが，基本的な政策だった。しかし，COVID-19による 都市と地方に対する見方の変化や，テレワークなどの急 速な進展により, 定住人口の拡大を目指す地域ブランディ ングの可能性が高まっている。

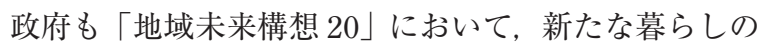
スタイルを確立するための施策として「リビングシフト (都市と地方の両方の良さを生かして働く・楽しむ生活)」 をあげており，それを推進する地方自治体を支援してい る 9)。しかし, 旅行で訪れるのと住むのでは, 地域に求 めるものが大きく異なり, 地域ブランディングの方法も 変わるため, 定住人口の拡大には未だ多くの課題が残さ れている10)。

\section{V. 結びにかえて}

本稿では，COVID-19 が地方に及ぼす影響に関して， 地域ブランディングの視点から考察してきた。

地方は, 外部資源に頼らなければ存続さえ危ういとい う構造的問題を抱えている。そこで, 自らの力で外部資 源を獲得するため, 地域ブランディングを活用し, 拡大 する交流人口を地方に取り込むことで地域活性化を図ろ うとしていた。これが, 地域活性化の “線”すなわち長 期的視点に立った地域ブランディングの基本戦略だった。

この基本戦略が, COVID-19 という “点”すなわち特 殊状況により大幅な変更を迫られる。COVID-19により 交流人口が激減したことで，地域内への顧客誘導から， 地域外への産品出荷という, かつての地域活性化策に逆 戻りしたのである。しかし, 単純に以前のやり方に戻っ たわけではない。以前の店舗やレストランを活用した間 接販売ではなく，インターネット等を利用した消費者へ の直接販売が大きくシェアを伸ばしている。ここに， COVID-19 下における地域外への産品出荷の特徴がある。

ところで, 地方は, COVID-19によって, 地域活性化の “線”すなわち交流人口の取り込みを完全に諦めたわけで はない。既存の交流人口の取り込みが困難になったこと で, マイクロツーリズムやオンライン体験ツアーなど新 たな交流人口の取り込み策を摸索している。

また，人々がこれらの新たなツーリズムを体験したこ とで, ツーリズムに対する価值観が変化し， COVID-19 の収束後は, それに対応した交流人口獲得のための地域 ブランディングが求められることも示した。

そして, COVID-19 は, 都市での生活に対する人々の 価值観にも影響を及ぼし, 地方での生活を求める人々す なわち定住人口のための地域ブランディングに対する関 心も高まっている。

最後に, COVID-19 が地域ブランディングに与えた理 論的示唆について少し触れておこう。COVID-19が私た ちに教えてくれたことのひとつに，困ったときに頼りに なるのは, 製品の良し悪しや価格で購入するかどうか判 断する顧客ではなく, それを生み出す生産者や地域との 関係を大切にする顧客だということである。本論で示し 
た「応援消費」はまさにそれを意味するものであり，顧 客を製品との関係からブランドすなわち生産者や地域と の関係へといかに導くかが，災害時だけではなく，平常 時の地域ブランディングにおいても重要な課題となるこ とを示唆している。平常時の地域ブランディングの成果 が，いま問われていると言えよう。

注

1）例えば, NHK で 2020 年 5 月 26 日に放送された「新型コロ ナウイルス スペインかぜからの教訓」(視点・論点) など を参照のこと（NHK，2020）。

2） 2014 年 12 月 27 日の閣議決定資料「まち・ひと・しごと創 生総合戦略」を参照のこと (Cabinet Office, 2014)。

3）池田内閣の国民所得倍増計画に関しては, Takeda（2014） 等を参照のこと。

4）石森は, この種のニューツーリズムを自律的観光と呼んで いる (Ishimori, 2001)。

5）（株）御菓子御殿 2021 年 1 月 21 日ニュースリリース参照 (Okashigoten Co., Ltd., 2021)。

6）三井住友カード（株） 2020 年 6 月 30 日ニュースリリース 参照（Sumitomo Mitsui Card Co., Ltd., 2020)。

7）農林水産省の事業には,「食ベチョク」の他に「豊洲市場 ドットコム」「技わざ」「【たべまる】食卓から応援！食べて つなげよう支援の輪」など多数の業者が参加している。な お，本事業は 2021 年 3 月 31 日で終了する予定。

8）開催日は 2020 年 10 月 30 日。募集人員は 20 名で参加費は 3,000 円となっている。オンラインとやまトラベルでは, こ れ以外にも，ッアー当日までに富山の老舗和菓子屋の上生 菓子を送り，ッアー当日にそれを楽しみながら，和菓子職 人が個々の参加者のリクエストに応じた和菓子を作る姿を 眺め, 後日それが旅の拉土産として届くというツアーも行っ ている。詳細は, オンラインとやまトラベルのウェブサイ 卜を参照のこと (Online Toyama Travel Secretariat, n.d.)。

9）「地域未来構想 $20 」$ およびリビングシフトに関しては,「地 域未来構想 20 オープンラボ」のウェブサイトを参照のこと (Cabinet Office, n.d.)。

10）地方移住に伴う問題に関しては, Nagano（2019）等を参照 のこと。また，交流人口促進と居住人口促進のための地域 ブランディングの違いに関しては, Kobayashi (2020) 等を 参照のこと。

\section{References}

BBC NEWS. (2020). Coronavirus pandemic could be over within two years - WHO head. BBC NEWS. Retrieved from https://www.bbc.com/news/world-53870798 (November 10, 2020).

Cabinet Office. (2014). Machi hito shigoto sosei sogo senryaku. Cabinet Office. Retrieved from https://www.kantei.go.jp/jp/ singi/sousei/info/pdf/20141227 siryou5.pdf (December 16, 2020). (内閣府 (2014)。「まち・ひと・しごと創生総合戦 略」『内閣府』）(In Japanese)
Cabinet Office. (2020). Dai 2-kai COVID-19 no eikyo-ka niokeru seikatsu-ishiki-kodo no henka nikansuru chosa. Cabinet Office, December 24, 1-67. Retrieved from https://www5.cao.go.jp/ keizai2/manzoku/pdf/result2_covid.pdf (January 24, 2021).（内 閣府 (2020).「第 2 回新型コロナウイルス感染症の影響下 における生活意識・行動の変化に関する調査」『内閣府』 12 月 24 日，1-67）(In Japanese)

Cabinet Office. (n.d.). Chiiki mirai koso20. Chiiki mirai koso open labo. Retrieved from https://www.miraikosou20-openlabo. go.jp/miraikousou20/ (January 20, 2021). (内閣府 (n.d.)「地 域未来構想 $20 」 『$ 『地域未来構想 20 オープンラボ』) (In Japanese)

Funada, U. (2020). With COVID-19 de ichiji-sangyo no kyuseisyu ni! Wadai-futtou-chu no TABECHOKU no user-gou ni web site kara semaru. Manamina, October 16. Retrieved from https://manamina.valuesccg.com/articles/1078 (December 20, 2020). (船田裕太 (2020). 「with コロナで一次産業の救世 主に！？話題沸騰中の食べチョクのユーザー像に Web サイ 卜分析から迫る」『マナミナ』10月16日）(In Japanese)

Hamaguchi, N. (2013). On the creative restoration. Journal of Economics \& Business Administration, 207(4), 35-46. (浜口伸 明 (2013).「創造的復興について」『国民経済雑誌』207(4), 35-46) (In Japanese)

Hoshino, Y. (2020). Hoshino resort ga teisho suru COVID-19 jidai no kankou "micro-tourism" towa. The Kyoto Shimbun, November 25. Retrieved from https://www.kyoto-np.co.jp/ articles/-/424828 (December 18, 2020).（星野佳路（2020）. 「星野リゾートが提唱するコロナ時代の観光「マイクロッー リズム」とは」『京都新聞』11月25日) (In Japanese)

Ishimori, S. (2001). Endogenous tourism-development and autonomous tourism. Senri Ethnological Reports, 21, 5-19. (石 森秀三 (2001a).「内発的観光開発と自律的観光」『国立民 族学博物館調查報告』21, 5-19)（In Japanese)

Iwashiro, H. (2018). Kankei-jinko niyoru chiho-sosyutsu. Mizuho Research Institute Working Papers, November 14, 1-12. Retrieved from https://www.mizuho-ri.co.jp/publication/ sl_info/working_papers/pdf/report20181114.pdf (January 24, 2021). (岩城博之 (2018).「関係人口による地方創出」『み ずほ総合研究所 Working Papers』11月 14 日, 1-12) (In Japanese)

Keller, K. L. (1993). Conceptualizing, measuring, and managing customer-based brand equity. Journal of Marketing, 57(1), 122.

Kobayashi, T. (2016). The theory and practice of place branding in Japan. Tokyo: Yuhikaku.（小林哲（2016）、『地域ブランディ ングの論理』有斐閣) (In Japanese)

Kobayashi, T. (2020). Impact of place brand performances on place brand's asset-value structure: Quantitative analysis using the refined place brand asset-value assessment model. Mita Business Review, 63(4), 183-202. (小林哲（2020).「地域ブ ランド成果の相違が地域ブランド資産 - 価值構造の評価に 与える影響 : 修正地域ブランド資産一価值評価モデルに基 づく定量分析」『三田商学研究』63(4), 183-202) (In Japanese)

Kotler, P., Haider, D. H., \& Rein, I. (1993). Marketing places: 
Attracting investment, industry, and tourism to cities, states, and nations. New York: Free Press.

Nagano, T. (2019). Inaka ni dete hitoata ageru! Chiho-ijyu genjyo to kadai wa. Asahi Shimbun, February 11. Retrieved from https://www.asahi.com/articles/ASM1R4TS5M1RULZU 00H.html (January 24, 2021).（長野剛（2019）。「田舎に出て 一旗揚げる! 地方移住，現状と課題は」『朝日新聞』2 月 11 日) (In Japanese)

NHK. (2020). Shingata-coronavirus: Spanish flu karano kyokun. News Commentators Bureau. Retrieved from https://www.nhk. or.jp/kaisetsu-blog/400/429818.html (November 20, 2020). (NHK（2020).「新型コロナウイルス スペインかぜからの 教訓（視点・論点）」『解説委員室』）(In Japanese)

Nikkan Kogyo Shimbun. (2020). "Ganso beni-imo tart" ga COVID-19 taisaku de itte. Nikkan Kogyo Shimbun, November 30. Retrieved from https://newswitch.jp/p/24849 (December 20, 2020). (日刊工業新聞 (2020)。「「元祖紅いもタルト」 がコロナ対策で一手」『日刊工業新聞』11月 30 日) (In Japanese)

Odagiri, T. (2019). "Kankei-jinko" towa nanika? CEL: Culture, Energy and Life, 123, 26-31. (小田切徳美 (2019). 「「関係人 口」とは何か? 一その背景・意義・可能性」『CEL: Culture, Energy and Life』123, 26-31) (In Japanese)

Oie, T. (2010). The new tourism and local tourism industry. Journal of Osaka University of Tourism, 10, 25-37. (尾家建夫 (2010). 「ニューツーリズムと地域の観光産業」『大阪観光大学紀要』 10, 25-37) (In Japanese)

Okada, Y. (2020). Corona-ka de jinko no chiho bunsan no kizashi. Mizuho Insight, Mizuho Research Institute Report, December 4, 1-9. Retrieved from https://www.mizuho-ri.co.jp/ publication/research/pdf/insight/pl201204.pdf (February 10, 2021). (岡田豊 (2020).「コロナ禍で人口の地方分散の兆 し」『みずほ総合研究所調査レポート』12月 4 日，1-9）(In Japanese)

Okamoto, T. (2020). COVID-19 go no ryoko wa 3-tsu no ten de okiku kawaru. Toyo Keizai, June 9. Retrieved from https:// toyokeizai.net/articles/-/354108 (December 20, 2020). (岡本岳 大 (2020).「「コロナ後の旅行」は “3つの点”で大きく変 わる」『東洋経済』6月 9 日) (In Japanese)

Okashigoten Co., Ltd. (2021). News release, January 21. Okashigoten Co., Ltd. Retrieved from https://www.okashigoten. co.jp/ news/11645/ (February 15, 2021). ((株) 御菓子御殿 (2021). 「ニュースリリース（1月 21 日)」『(株) 御菓子御殿』) (In Japanese)

Online Toyama Travel Secretariat. (n.d.). Online TOYAMA Travel. Online Toyama Travel Secretariat. Retrieved from https:// www.online-toyama.jp/\#travels (January 24, 2021). (オンライ ンとやまトラベル事務局（n.d.）.「オンラインとやまトラベ ル」『オンラインとやまトラベル事務局』) (In Japanese)

Sumitomo Mitsui Card Co., Ltd. (2020). News release, June 30. Sumitomo Mitsui Card Co., Ltd. Retrieved from https:// www.smbc-card.com/company/news/news0001533.jsp (December 20, 2020). (三井住友カード (株) (2020).「ニュー スリリース（6月 30 日)」『三井住友カード（株)』）(In
Japanese)

Takeda, H. (2014). Kokumin shotoku baizo keikaku wo yomitoku. Tokyo: Nihon Keizai Hyoron-sha.（武田晴人（2014）. 「国民 所得倍増計画」を読み解く」『日本経済評論社』) (In Japanese)

The Japan Tourism Agency Strategy Planning Division. (2015). Heisei 26-nen hounichi gaikokujin kanko-kyaku no chiho homon jyokyo. The Japan Tourism Agency Strategy Planning Division. Retrieved from https://www.mlit.go.jp/common/ 001107179.pdf (December 20, 2020). (観光庁観光戦略課調査 室（2015）。「訪日外国人消費動向調査【トピックス分析】 平成 26 年訪日外国人観光客の地方訪問状況」『観光庁観光 戦略課調査室』) (In Japanese)

The Okinawa Times. (2020). Okinawa miyage no teiban "beni-imo tart" uriage hangen. Zaiko 5-bai de noka mo kukyo. The Okinawa Times, November 13. Retrieved from https:// www.okinawatimes.co.jp/articles/-/662982 (December 20, 2020)。(沖縄夕イムズ (2020)。「沖縄土産の定番「紅いも夕 ルト」売上半減 在庫 5 倍で農家も苦境」『沖縄タイムズ』 11 月 13 日) (In Japanese)

The Ryukyu Shimpo. (2020). Beni-imo chinsuko mo ‥ Miyagehin ni tairyo-haiki no kiki. The Ryukyu Shimpo, April 26. Retrieved from https://ryukyushimpo.jp/news/entry-1113221.html (December 20, 2020). (琉球新報（2020）.「紅いもタルト， ちんすこうも…産品に大量廃棄の危機」『琉球新報』4月 26 日) (In Japanese)

Tomimoto, M. (2016). Study on cultural tourism as new tourism: Through the view from opposition to symbiosis. Bulletin of Gifu Women's University, 45, 59-67. (冨本真理子 (2016). 「ニューツーリズムとしての文化観光一対立から共生の視点 を通じて一」『岐阜女子大学紀要』45, 49-67）(In Japanese)

\section{小林 哲（こばやしてつ）}

明治学院大学経済学部卒業。慶應義塾大学大学院商学研究 科後期博士課程単位取得退学。博士 (商学)。現在, 大阪市 立大学経営学研究科教授。専門は, 地域ブランディングと フードビジネス。 